\title{
Interdisciplinarity, E-Mentoring and Support of Entrepreneurial Research Skills
}

\author{
Ileana Hamburg \\ Institut Arbeit und Technik \\ Westfälische Hochschule Gelsenkirchen, Germany
}

\begin{abstract}
Innovation requires the development of entrepreneurial skills in order to provide a new approach to the work and solutions to a challenge in the corresponding enterprise. Research skills can help entrepreneurs throughout your career i.e. to develop an innovative project, to find an answer to a question. to find data and information about a topic, analyze and interpret this information to find a solution. Mentoring is understood mostly as a supportive relationship to guide the successful integration of new members/entrepreneurs into an organization or to help entrepreneurs to be innovative and add value to the organization. E-mentoring helps a mentee to obtain knowledge with the support of a mentor who is physically not present but using digital technologies. One important conceptual change regarding mentoring in both business and education is the emphasis on the need for more than a single mentor i.e. networks of mentors who may provide both technical careers advancing advice and psychosocial support. Interdisciplinary mentorship is a tool of scientists and entrepreneurs to help produce synergy in groups, and to generate multifocal ideas and complex solutions to complex challenges. This paper examines entrepreneurial learning, mentoring and entrepreneurial research skills as main factors for development of innovation in companies. An example of a project in the context of achieving workplace-oriented research skills of entrepreneurs is given. A part of the project runs within the Coronavirus crisis, so entrepreneurs learn and interact mainly by using a digital platforms and E-mentors.
\end{abstract}

\section{INTRODUCTION}

Landreth and Colander (1994), affirmed "...the real source of economic growth is fostered by the activities of the innovative entrepreneur not in the activities of the followers who are risk averse." An entrepreneur would like to have achievements in any engaged (McClelland, 1961), is proactive instead of reactive (Miller, 1983) being innovative and creative (Drucker, 1985), is able to take risks and has an internal focus of control (Brockhaus, 1982). The innovation could not take place without development of entrepreneurial skills of such people, who participate in the production relations in this context. To possess such skills in innovation sphere means to provide a new approach to the work with additional skills and solutions to a challenge in the corresponding enterprise.

Research skills are essential for entrepreneurs because they help the company to develop new products or services, identify the needs and wants of their customers, improve what they do, keep 
up with changes in their industry and compete in their market. Knowing how to develop research skills and highlight them for employers can help entrepreneurs in several ways throughout your career (https://www.indeed.com/career-advice/career-development/research-skills). Research skills help to develop an innovative project, to find an answer to a question or a solution to a problem and include i.e. the ability to find data and information about a topic, analyze and interpret this information to find a solution (Hamburg et al., 2019).

Mentoring is a supportive relationship to guide the successful integration of new members/entrepreneurs into an organization or to help entrepreneurs to be innovative and add value to the organization (Bland et al., 2009; Zellers et al., 2008).

Since the work of Kram (Kram and Isabella 1985), a lot of research on mentoring has been done about its potential to benefit mentees' careers (Allen et al. 2008) including in entrepreneurship. Some gaps in knowledge with regard to entrepreneurial skills remain. Research on mentoring outcomes in general within a university or company context exists but only few examines whether mentoring helps to achieve particularly skills like research ones to shape entrepreneurial innovative outcomes. Addressing such student outcomes is necessary because of the increasing use of different forms of innovation and new digital technologies. E-mentoring, one of the mentoring methods, helps a mentee to obtain knowledge and accelerate growth with the support of mentor who is physically not present but using digital technologies. Career aspirations and personal development are other benefits one can be obtained also with the proper mentoring, but. main advantages of E-mentoring could be the easy availability of online networking websites and digital applications, to interact, by using digital platform, to post query and not being bounded by geographical location.

One important requirement in both business and education is to use more than a single mentor (DeCastro et al., 2013; Pololi \& Knight, 2005; Sullivan, 2004; Ibarra, 1993). Networks of mentors who may provide both technical careers advancing advice and support for psychosocial needs and interdisciplinary mentoring become more importance.

This paper examines the particularities and necessity of entrepreneurial research skills as a condition for development of innovation and discusses what research skills are, why they are important, how they can be achieved within entrepreneurial learning and used throughout entrepreneur career.

How can interdisciplinary and networks of mentors help to achieve entrepreneurial skills particularly research skills are also shortly presented. An example of a project in the context of achieving workplace-oriented research skills of entrepreneurs is given. A part of the project runs within the Coronavirus crisis, so entrepreneurs learn and interact mainly by using a digital platforms and E-mentors (https://www.abacademies.org/articles/ementoring-alternativeparadigm-for-entrepreneurial-aptitude-development-8067.html). 
Hamburg, I. (2020) Interdisciplinarity, E-Mentoring and Support of Entrepreneurial Research Skills. Advances in Social Sciences Research Journal, 7(4) 298-309.

\section{ENTREPRENEURIAL SKILLS}

In https://www.mindtools.com/pages/article/newCDV_76.htm.some characteristics of successful entrepreneurs are given:

\section{Personal skills}

- Optimism: will help to get through the tough times that many entrepreneurs experience as they find a business model that works for them

- Vision: to deal when things can be improved, create a vision of the future and inspire other people to engage with that vision

- Initiative: and instinctively start problem-solving or business improvement projects

- Desire for Control: being in charge and making decisions

- Drive and Persistence: being self-motivated and energetic and prepared to work hard, for a very long time, to realize planned goals

- Risk Tolerance: to take risks, and make decisions when facts are uncertain

- Resilience: learn and grow from own mistakes and failures

- Flexibility: be willing to change as needed.

\section{Interpersonal Skills}

- Work closely with people: to build great relationships with own team, customers, suppliers, shareholders, investors, and more.

- Leadership and Motivation

- Communication Skills: being competent with all types of communication

- Listening: hear what others are telling

- Personal Relations: be emotionally intelligent

- Negotiation: not only negotiate keen prices but be able to resolve differences between people in a positive, mutually beneficial way.

- Ethics: deal with people based on respect, integrity, fairness, and truthfulness

\section{Critical and Creative Thinking Skills}

- Creative Thinking: being able to see situations from a variety of perspectives and come up with original ideas

- Problem Solving: coming up with sound solutions to the problems you're facing

- Recognizing Opportunities: when they present themselves

To cope with digital transformation the entrepreneurs need additional skills in artificial intelligence, nanotechnology, robotization, internet of things, augmented reality, digitalization.

Research Skills enable people to identify a problem, collect informational resources that can help address the problem, evaluate these resources for quality and relevance and come up with an effective solution to the problem (https://www.reachivy.com/wp-content/uploads/2016/07/Why-Are-Research-SkillsImportant_-How-Do-I-Develop-Them_.pdf). 
Some research skills which are identified in (https://www.indeed.com/career-advice/careerdevelopment/research-skills) which could help entrepreneurs in their careers are:

1. Searching for credible data and information that can be analyzed and use to arrive at an answer or solution. In the workplace, the information help to develop and run projects which add value to the company.

2. Attention to detail and taking notes involve the ability to gather important information; summarize it in writing to referenced later. Knowing how to take good notes will help in several ways throughout own career.

3. Time management skills refer to the ability to break down projects into manageable parts, make a deadline-oriented plan and complete each section the plan by scheduled deadline. It involves setting goals, planning, organizing, delegating and prioritizing tasks.

4. Problem-solving skills refer to the ability to handle difficult situations and overcome complex business challenges. It involves the ability to break a problem down into its parts, think critically about each element, analyze the founded information and use that information to form an effective solution.

5. In (https://www.indeed.com/career-advice/career-development/research-skills) some methods to develop research skills are done which we used for developing a training program within the Erasmus+ project ReInnovate (see later).

6. Make an outline: when starting any research project make an outline to help guide it. including a plan for the questions research and the information needed to arrive at a decision. It should also include a plan to divide the research project into manageable parts and a schedule detailing when each piece of the project should be complete.

7. Know necessary sources: it is important to know how to find reliable sources and analyse information to determine whether or not it is credible. Locate the original information source to verify its reliability.

8. Learn to use advanced search techniques: using the internet for research, most search engines allow to use advanced search preferences to customize own search results. These search techniques will help to find the necessary information.

9. Practice: developing research skills by creating small research projects that can help i.e. with a current life event.

\section{ENTREPRENEURIAL LEARNING}

One of the main causes leading to the failure of start-up businesses or digital ones is the lack of experience and competence of entrepreneurs, their lack of vision and their difficulty or inability to find a profitable niche for the new business (Baldwin et al. 1997; Festervand and Forrest 1991; Gaskill et al. 1993). An overall increase of entrepreneur's skills and knowledge within the first years of a company's life is important. Some authors even claim that entrepreneurial learning can influence business growth (Deakins and Freel 1998; Priyanto and Sandjojo 2005). Learning is the act or process by which behavioral change, knowledge, skills, and attitudes are acquired.

Entrepreneurship is seen as learning process in itself. Entrepreneurial learning relates to the entrepreneur's development of new interpretations through a process of seeking and recognizing opportunities, and to the way he manages and organizes his business (Rae and Carswell 2001). Five main entrepreneurial learning areas are important: learning about oneself, learning about the business, learning about the environment and entrepreneurial networks, learning about small business management, and learning about the nature and management of relationships. 
Hamburg, I. (2020) Interdisciplinarity, E-Mentoring and Support of Entrepreneurial Research Skills. Advances in Social Sciences Research Journal, 7(4) 298-309.

Entrepreneurial learning (Hamburg et al., 2018; Politis, 2005) is important for achieving skills of entrepreneurs because:

- creates conditions for job creation and a stable economy

- stimulates different forms of innovation and the capacities to deal with exponential change and globalization

- engages and motivates entrepreneurs through relevant learning experiences for education, life and work.

- empowers people to create value for society and deal with societal challenges.

But pedagogical approaches to developing research skills are limited for an academic environment and little within entrepreneurial education. Information and research skills in the workplace are important but little research has been done on how to develop workplace research skills at entrepreneurs to be more personalized, to enhance entrepreneurial culture and innovation. In order to exploit research skills as a method of developing entrepreneurial capacity in companies, require methods are necessary which align to both the pedagogy of developing research skills and entrepreneurial education. Inquiry based teach (Pedaste et al., 2015) is a methodology which is adopted in both contexts. Problem-based learning and the importance of reflection at both the individual level (metacognition) and organizational level (reflective practice) are key in developing entrepreneurial research skills (O’Brien et al, 2018).

\section{INTERDISCIPLINARY MENTORING, NETWORKING AND E-MENTORING}

The training needs of entrepreneurs particularly new ones are not always addressed in the design of their support programs within entrepreneurial education programs. Entrepreneurs affirm that the training they receive is not always tailored to their needs, suggesting that a more personalized learning process could be appropriate (Dokou 2001). Research suggests that mentoring is a personalized approach to help a novice entrepreneur develop business management skills (Bisk 2002; Sullivan 2000) and can be used also for developing research skills. If there is not enough time for training, interaction with a mentor could facilitate a quick and efficient transfer of experience into learning.

With regards to entrepreneurial mentoring, the small number of studies makes it difficult to find a generally agreed upon definition. Entrepreneurial mentoring involves a support relationship between an experienced entrepreneur (the mentor), and a novice entrepreneur (the mentee), in order to foster the latter's personal development or help entrepreneurs within new career ways. The form of accompaniment can vary from formal to informal forms. A number of remote mentoring programs - E-mentoring have been developed, where participants conduct virtual meetings (Perren, 2003). E-Mentoring can improve the performance of students by assisting mentors to understand the problems of students more effectively and easily by using digital technology.

Mentorship is a collaborative learning process that draws upon the knowledge of experts who can provide guidance (Kram \& Isabella, 1985) to new entrepreneurs or to seniors transitioning to new roles. The relationship is a "reciprocal, supportive, and creative partnership of equals" (Kram \& Isabella, 1985). Mentoring requires active committed engagement of both mentor and mentee. It is dependent on willingness of those acting as mentors to invest time for guidance on an ongoing basis. It also requires the commitment of mentees to actively identify specific developmental goals and to 
invest time and energy to achieve them. Mentoring should help i.e. novel entrepreneurs to successfully acquire the key competencies, as well as the constructive professional relationships (professional networks) within the organisation and beyond needed to develop a productive career (Zellers et al., 2008; Bhagia \& Joyce, 2000). The traditional, hierarchical, dyadic mentoring relationships can be completed by an additional network of individuals providing very specific guidance in areas of professional development that may not be addressed within a single dyadic relationship (Zellers et al., 2008; Kram \& Isabella, 1985).

Mentoring need not be limited to novel entrepreneurs because also senior employees want to focus on career transitions and new directions. The structure of these relationships may be less formalized and more dependent on peer or near peer relationships; professional "coaching" (https://provost.columbia.edu/sites/default/files/content/MentoringBestPractices.pdf).

Mentoring relationships are not constant and should focus on elements required for career success depending upon the career stage of the mentee, the career goals to be met, the level of guidance required, and the nature of the input from mentors. Sometimes long-term relationships evolve into collegial rather than mentoring relationships, or they may be more transient relationships focused on specific areas of guidance at key career points (https://www.researchgate.net/publication/225629671_The_role_of_mentoring_in_the_learning_ development_of_the_novice_entrepreneur).

Mentors roles can be "technical or instrumental career functions" and "psychosocial or expressive career functions" (Zellers et al., 2008; Ibarra, 1993; Mitchell, 1999). Technical or instrumental career functions could be as aadvisor for overall professional goals and career choices, facilitator of professional networking within and outside of the company, sponsor who provides specific strategic opportunities with career relevance. Psychosocial or expressive career functions includes i.e. Advocate, Role model, Intellectual challenger.

Due to greater diversity of the tasks and experts it may be unrealistic to expect a single individual to perform all roles equally well. Thus, the value of the concept of multiple mentors and mentoring networks has become considerably more important in recent years (Sullivan, 2000).

Interdisciplinary mentoring has become more important in the last years due to the facts that research and different innovative developments and fields are increasingly multidisciplinary. Interdisciplinary mentorship is the tool of scientists and entrepreneurs to help produce synergy in groups, and to generate multifocal ideas and complex solutions to complex challenges. A community of diverse scientists/experts can be unified by mentoring connections or networks which will create opportunities to establish collaborations and work in an interdisciplinary mode. Multiple mentors who may provide both technical careers advancing advice and support for psychosocial needs are important components of a mentoring network.

DeCastro et al. (2013a) surveyed $100 \mathrm{NIH}$ research grant recipients and 28 research mentors regarding their mentorship experiences and found that the need for more than a single mentor emerged as a recurrent theme in interviews with both mentors and mentees. The size of network, the range (the diversity of positions or roles of members within the network), the strength of the 
Hamburg, I. (2020) Interdisciplinarity, E-Mentoring and Support of Entrepreneurial Research Skills. Advances in Social Sciences Research Journal, 7(4) 298-309.

ties and longer duration of network relationships were network characteristics positively correlated with greater career success and satisfaction.

\section{METHODOLOGY AND RESULTS: A TRAINING MODEL FOR DEVELOPING RESEARCH SKILLS}

It is known that innovation involves the utilization of new knowledge or a new use or combination of existing knowledge. Entrepreneurial education providers have long been sources of this knowledge but often i.e. higher education produce 'general research'. An internal research capacity and employees' skills are required to allow companies to adapt and use results to the company requirements and particularly their business. However small and medium sized enterprises (SMEs) often do not have this internal capacity due to limited resources.

ReInnovate project complements this need by developing research skills for SME entrepreneurs to enable them to absorb new knowledge and innovations offered by external sources such as research and education institutes and conduct small scale research projects.

Traditionally research skills are taught as part of an academic program and are delivered from an academic perspective. These are not designed with the requirements for work-oriented research skills from an SME entrepreneur perspective. ReInnovate partners have conducted a needs analysis to design an entrepreneurial training program to learn and use research skills as a basis to enable SMEs to develop the knowledge they need to create innovative ideas and translate this knowledge into value. This will enable companies to become more entrepreneurial innovative.

Main activities of ReInnovate are

1. Development of a learning methodology and accredited curriculum to support the development of practice-based research skills of SME entrepreneurs.

2. Design a level 6 higher certificate in practice-based research to teach these skills in modules to entrepreneurs in SMEs. The modules will be based on the need's analysis and the ENTRECOMP framework and will help to develop entrepreneurial mindset in SMEs

3. Development of digital tools to support an interdisciplinary mentoring and achievement of research skills in SMEs. This will provide flexible pathways for SME learners

4. Piloting these modules and tools with SME entrepreneurs to ensure it meets the requirements identified in EU policies and the needs analysis

5. Transferring the methodology to other sectors and VET programs

6. Designing cooperation models between companies, research and education.

Project partners are SMEs organizations and representatives, higher education and research institutions from five European countries. The main learning methods within ReInnovate is inquirybased learning and problem-based learning ( $\mathrm{O}^{\prime} \mathrm{Brien}$ et al, 2019). It is organized into inquiry phases that form an inquiry cycle. However, different variations on the inquiry cycle can be found throughout the literature. The pedagogy of inquiry-based learning that is in use within the ReInnovate program is based on the framework outlined by Pedaste et al (2015), who provided a synthesized inquiry based learning framework that identifies five distinct general inquiry phases: Orientation, Conceptualization, Investigation, Conclusion and Discussion. Some of these phases are divided into sub-phases including Questioning, Hypothesis Generation, Exploration, Experimentation, Data Interpretation, Reflection; and Communication. 
The ReInnovate training program "Smart Research as a 21st Century Skill for Business" is structured across four modules. The four modules within this program are:

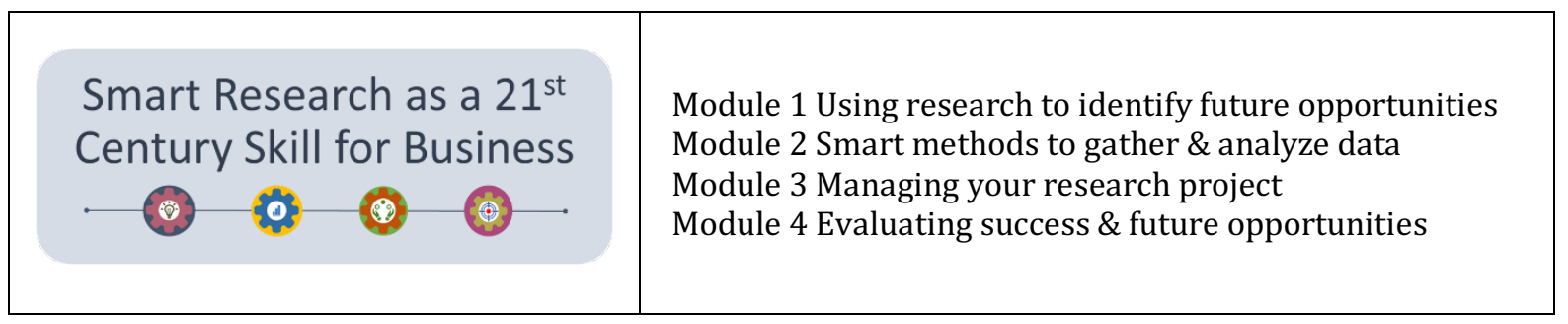

Each module consists of a number of units and topics and these are outlined hereunder (Module1: Figure 1; Module 2: Figure 2; Module 3: Figure 3; and Module 4: Figure 4):

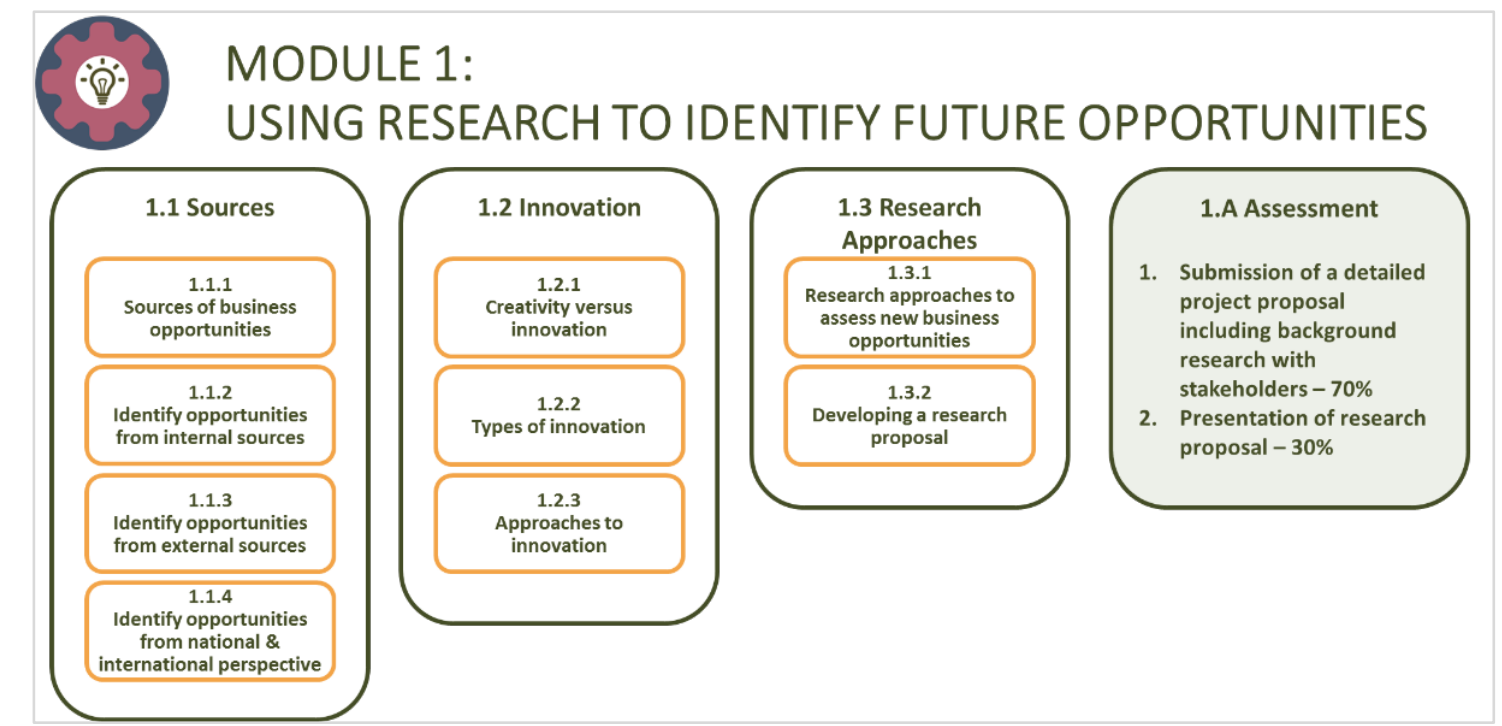

Figure 1 Module 1 Using Research to Identify Future Opportunities

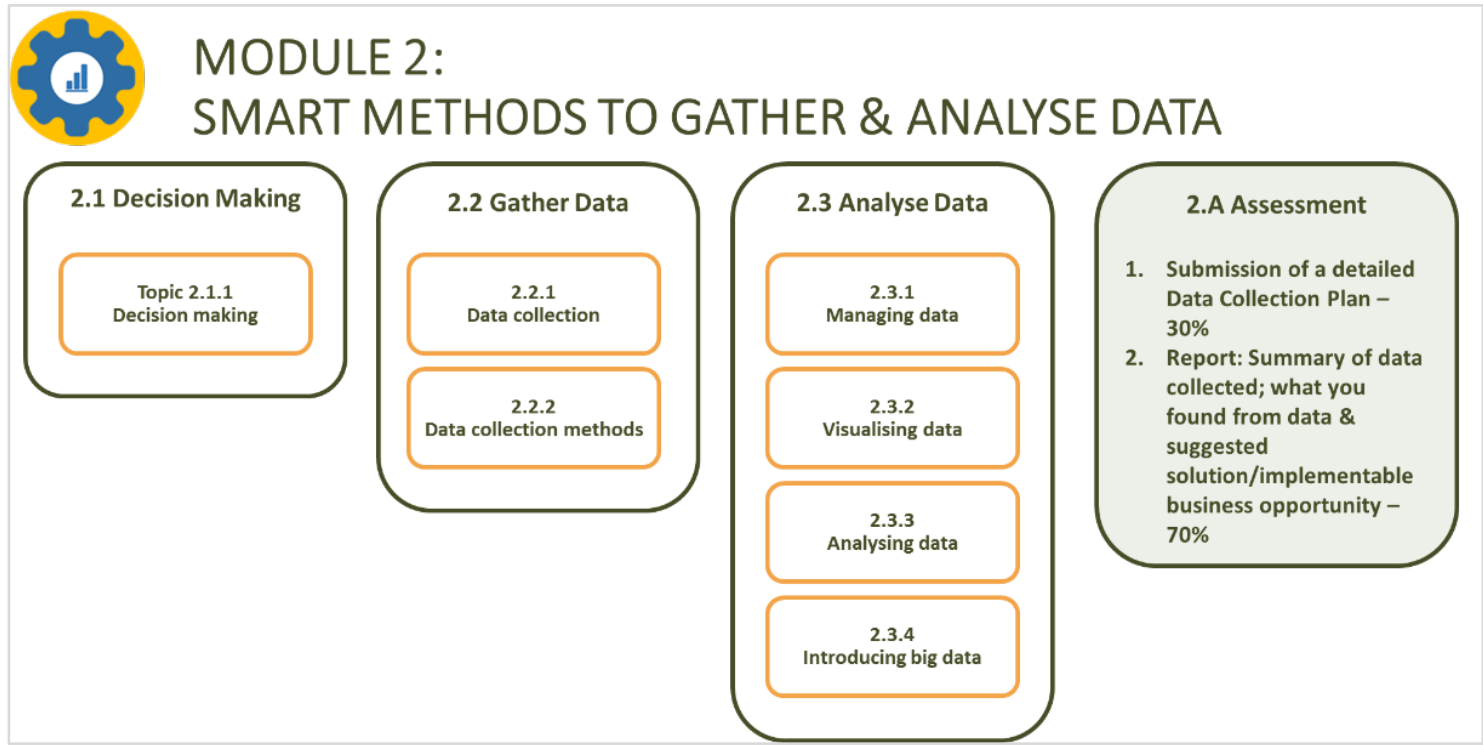

Figure 2 Module 2 Smart Methods to Gather \& Analyse Data 


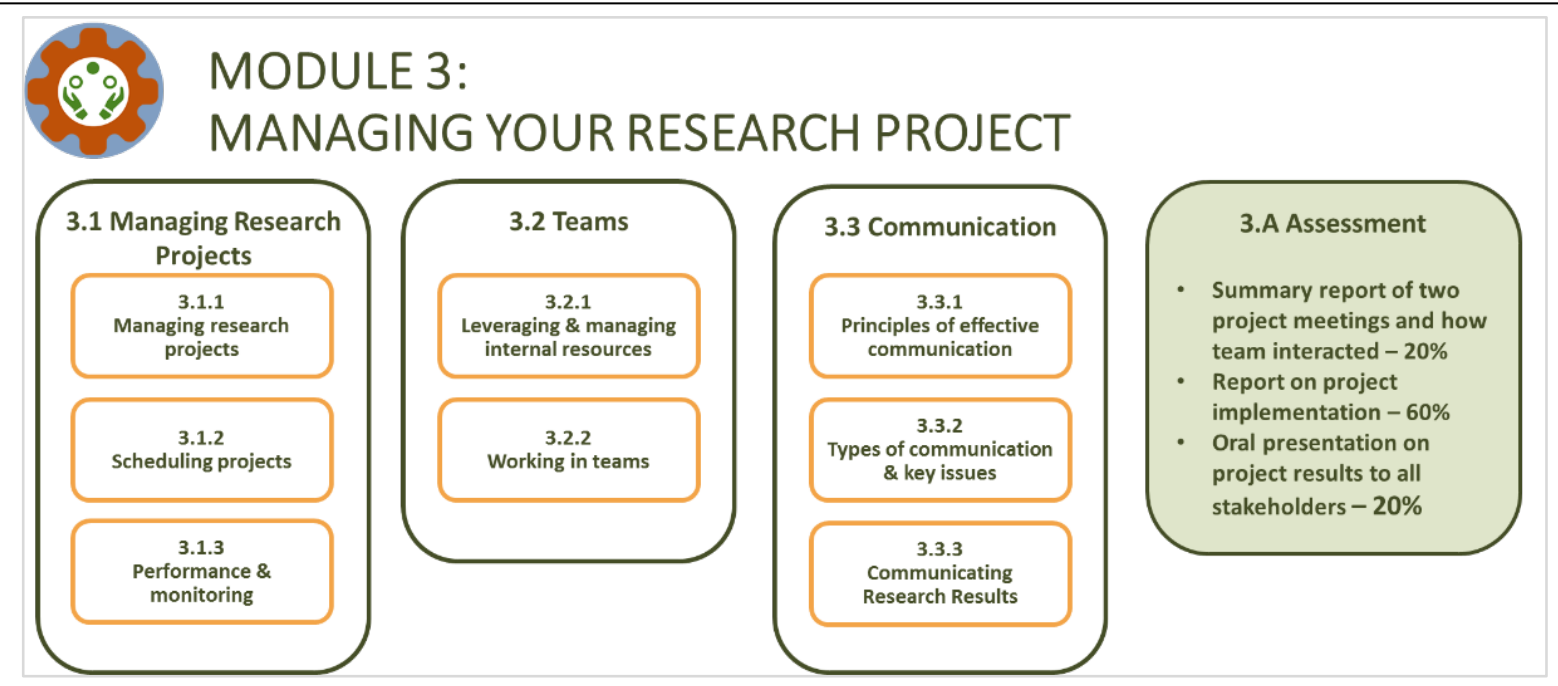

Figure 3 Module 3 Managing Your Research Project

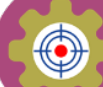

MODULE 4:

EVALUATING SUCCESS \& FUTURE OPPORTUNITIES

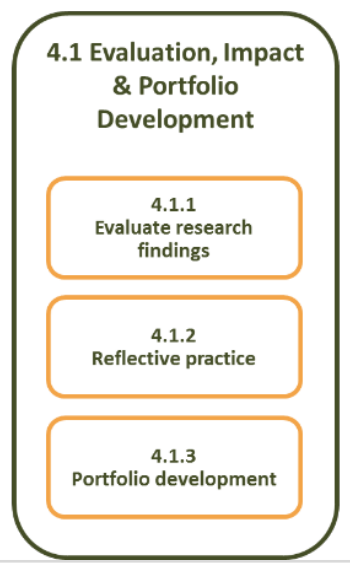

4.A Assessment

1. Evaluation map with future research plan $30 \%$

2. Reflective learning journal $-30 \%$

3. Development of an eportfolio $-40 \%$

Figure 4 Module 4 Evaluating Success \& Future Opportunities

A part of the project runs within the Coronavirus crisis so entrepreneurs learn and interact mainly by using a digital platforms (http://www.reinnovate2017.eu/elearning/and E-mentors (https://www.abacademies.org/articles/ementoring-alternative-paradigm-for-entrepreneurialaptitude-development-8067.html).The training modules are available in all partner languages and presented on the platform. The first weeks of the training were dedicated to getting learners comfortable with the program and with the platform. E-mentors from different disciplines (in order to give support within all modules) and a tutor are provided by each partner.

Each week the tutor hold one on-line tutorial briefing learners of what is required from them for that week. This is held online and cover the following:

- What learning material they must cover for the week and a short summary of it

- What tasks they must complete for the week

- What assignment work needs to be completed 
The tutor should monitor the forums daily and answer learner queries ASAP. For all of the activities the tutor should ensure that all learners are participating.

\section{CONCLUSIONS}

Entrepreneurial skills particularly research ones are formed, consolidated and, finally, realized by separate individuals due to certain abilities, characteristic to each individual in varying degrees (Korobov et al., 2017). These separately identified abilities determine own general entrepreneurial ability, as well as ability to engage in entrepreneurship in innovation. Cooperation within entrepreneurial education and interdisciplinarity are also necessary. Mentoring offers an opportunity particularly for novice entrepreneurs in a context where there exist difficulties in obtaining proper training, particularly due to a lack of time and resources, which are often a byproduct of starting up a business (Politis, 2005).

Mentoring is particularly helpful in allowing a transfer of knowledge about the business world, and developing a competence set that will be useful to the entrepreneur, within the limits of what the mentor can offer. Many entrepreneur mentees have developed an improved vision for their business and others have identified new business opportunities to pursue.

Mentors can contribute to the development of certain types of learning. Discussions, explanations, questioning, and working together are especially useful to the development of cognitive learning, encouragement and modeling foster the development of affective learning. Digital technology within E-mentoring affects both mentor and mentee through its interaction with individual factors and technology is affected by situational factors, social factors, perceived ease of use and perceived usefulness. E-mentoring could be used on a variety of programs to specific groups and also in specific situations (https://www.abacademies.org/articles/ementoring-alternative-paradigm-forentrepreneurial-aptitude-development-8067.html).

\section{References}

Allen, T. D., Eby, L. T., Poteet, M. L., Lentz, E., \& Lima, L. (2004). Career benefits associated with mentoring for protégés: A meta-analysis. Journal of Applied Psychology, 89(1), 127-136.

Baldwin, J., Gray, T., Johnson, J., Proctor, J., Rafiquzzaman, M., \& Sabourin, D. (1997). Les faillites d'entreprise au Canada. Rapport no. 61-525-XIF. Ottawa: Statistique Canada.

Bhagia, J., \& Joyce A. (2000). The mentoring partnership. Mayo Clinic Proceedings, 75(5), 535-537.

Bisk, L. (2002). Formal entrepreneurial mentoring: the efficacy of third-party managed programs. Career Development International, 7(5), 262-270.

Bland, C. J., Taylor, A. L., Shollen, L. S., Weber-Main, A. M., \& Mulcahy, P. A. (2009). Faculty success through mentoring. Lanham, MD: Rowman \& Littlefield Education.

Brockhaus, R.H. (1982), “The psychology of the entrepreneur”, Encyclopedia of Entrepreneurship, Prentice-Hall, Englewood Cliffs, NJ. 39-56.

Deakins, D., Graham, L., Sullivan, R., \& Whittam, G. (1998). New venture support: an analysis of mentoring support for new and early stage entrepreneurs. Journal of Small Business and Enterprise Development, 5(2), 151-161.

DeCastro, R., Sambuco, D., Ubel, P. A., Stewart, A., \& Jagsi, R. (2013b). Batting 300 is good: Perspectives of faculty researchers and their mentors on rejection, resilience, and persistence in academic medical careers. Academic Medicine, 88(4): 497-504. 
Hamburg, I. (2020) Interdisciplinarity, E-Mentoring and Support of Entrepreneurial Research Skills. Advances in Social Sciences Research Journal, 7/4) 298-309.

Dokou, G. K. (2001). Accompagnement entrepreneurial et construction des facteurs clés de succès. Xe Conférence de l'AIMS, Université Laval (Québec).

Drucker P F, Noel J L 1986 Innovation and entrepreneurship: Practices and principles Journal of Continuing Higher Education 34 (1) 22-23 ??E St-Jean, J Audet The role of mentoring in the learning development of the novice entrepreneur - International Entrepreneurship and Management ..., 2012 - Springer.

Festervand, T. A. \& Forrest, J. E. (1991). Small business failures: A framework for analysis. Orlando: Small Business Institute Director's Association Conference.

Gaskill, L. R., Van Auken, H. E., \& Manning, R. A. (1993). A factor analytic study of the perceived causes of small business failure. Journal of Small Business Management, 31(4), $18-31$.

Hamburg, I., O'Brien, E., Öz, F. (2019): Chapter 2: Entrepreneurship \& research skills in SMEs. In: Dirksen, Daan: The power of entrepreneurship. New York: Nova Science Publishers,.45-76.

Hamburg, I., O'Brien, E., Vladut, G. (2018). Workplace-oriented research and mentoring of entrepreneurs: cooperation university - industry. Archives of business research, no. 6, 243-25.

Ibarra, H., \& Hunter, M. (2007). How leaders create and use networks. Harvard Business Review, 85(1), 62-70.

Korobov S A, Moseiko V O, Marusinina E Y, Novoseltseva E G, Epinina V S 2017 The substance of a rational approach to entrepreneurship socio-economic development Contributions to Economics 207-223.

Kram, K. (1985). Mentoring at work: Developmental relationships in organizational life. Glenview, IL: Scott, Foresman.

Kram, K. E., \& Isabella, L. A. (1985). Mentoring alternatives: The role of peer relationships in career development. Academy of Management Journal, 28(1), 110-132.

Landreth, H. and Colander, D. (1994), History of Economic Thought, 3rd ed., Houghton Mifflin, Toronto.

McClelland, D.C. (1961), The Achieving Society, D. Van Nostrand Company, Inc., Princeton, NJ.Miner, A. S., Ciuchta, M. P., et al. (2008). 'Organizational Routines and Organizational Learning'. Handbook of Organisational Routines. M. C. Becker. Cheltenham, Edward Elgar: 152-186.

Miller, D. (1983), “The correlates of entrepreneurship in three types of firms”, Management Science, Vol. 29 No. 7, pp. 770-91.

Mitchell, H. J. (1999). Group mentoring: does it work? Mentoring \& Tutoring, 7(2), 113-120.

O'Brien, E. McCarthy, J., Hamburg, I.Delaney, Y. (2019)2019: Problem-based learning in the Irish SME workplace. In: Journal of workplace learning 31, no. 6, 391-407.

Pedaste, M., Mäeots, M., Siiman, L. A., de Jong, T., van Riesen, S. A. N., Kamp, E. T., Tsourlidaki, E. (2015). Phases of inquiry-based learning: Definitions and the inquiry cycle. Educational Research Review, 14, 47-61.

Perren, L. (2003). The role of e-mentoring in entrepreneurial education and support: a meta-review of academic literature. Education + Training, 45(8/9), 517-525.

Politis, D. (2005). The process of entrepreneurial learning: a conceptual framework. Entrepreneurship Theory and Practice, 29(4), 399-424.

Pololi, L., \& Knight, S. (2005). Mentoring faculty in academic medicine. A new paradigm? Journal of General Internal Medicine, 20(9), 866-870.

Plowright, D. 2016. Developing Doctoral Research Skills for Workplace Inquiry: Using an Intergrated Methodology, in M. Fourie-Malherbe, R. Albertyn, C. Aitchison \& E. Bitzer. (eds.). Postgraduate Supervision: Future Foci for the Knowledge Society. Stellenbosch: SUN PRESS. 241-254.

Priyanto, S. H. \& Sandjojo, I. (2005). Relationship between entrepreneurial learning, entrepreneurial competencies and venture success: empirical study on SMEs. International Journal of Entrepreneurship and Innovation Management, 5(5/6), 454-468.

Rae, D. \& Carswell, M. (2001). Towards a conceptual understanding of entrepreneurial learning. Journal of Small Business and Enterprise Development, 8(2), 150-158. 
E St-Jean, J Audet -The role of mentoring in the learning development of the novice entrepreneur International Entrepreneurship and Management ..., 2012 - Springer.

Sullivan, R. (2000). Entrepreneurial learning and mentoring. International Journal of Entrepreneurial Behaviour \& Research, 6(3), 160-175.

Zellers, D. F., Howard, V. M., \& Barcic, M. A. (2008). Faculty mentoring programs: Reenvisioning rather than reinventing the wheel. Review of Educational Research, 78(3), 552-588. 